\title{
Online Learning Policies and Indonesian Language Learning Constraints during the Covid-19 Pandemic
}

DOI: https://doi.org/10.47175/rielsj.v2i4.360

\author{
${ }^{1,2}$ Indonesian Language and \\ Literature Education, Faculty \\ of Language and Arts \\ Yogyakarta State University, \\ Colombo Street, Sleman, \\ Yogyakarta, Indonesia \\ ${ }^{1}$ muhammadagung.2020@stud \\ ent.uny.ac.id, \\ 2hartono-fbs@uny.ac.id
}

| Muhammad Agung Wibisono ${ }^{1}$ | Hartono ${ }^{2}$ |

\begin{abstract}
This research aims to analyze online learning policies and the problems of obstacles of teachers, learners, and parents in learning Indonesian in the covid-19 pandemic. This type of research is a case study at Muhammadiyah 4 Yogyakarta Junior High School and literature study using secondary data collected through books, journals, websites, and other sources related to research problems. Data collection uses interview techniques and document analysis. Data analysis uses qualitative descriptive techniques, consisting of data collection and subtraction, data presentation, and conclusion withdrawal. The results showed that the distance learning policy implemented at Muhammadiyah Junior High School 4 Yogyakarya was in accordance with the Circular Letter (SE) of the Ministry of Education No. 4 of 2020 on the Implementation of Education Policy in the Emergency Period of The Spread of Coronavirus Disease (COVID-19). The policies implemented include policies to provide student learning experiences, provide life skills education, learning in accordance with student conditions, the process of awarding assessments, and the process of Admission of New Learners (PPDB) and School Operational Assistance (BOS). On the other hand, there are also learning obstacles for teachers, learners, and parents in Indonesian learning experienced during the diverse covid-19 pandemic. Teacher constraints are on aspects of the use of learning applications, weak internet network access, unpreparedness with online learning media, learning materials that cannot be applied optimally, and research to learners. Student constraints are on aspects of inadequate learning facilities, weak internet access, inactivity in following learning, psychological conditions of stress and boredom, many tasks, and difficulties in operating learning applications. Parental constraints are on socio-economic aspects and supervision or mentoring of children in online learning at home.

KEYWORDS

policy; online learning; problems; language learning; covid-19 pandemic
\end{abstract}

\section{INTRODUCTION}

The covid-19 virus is spreading around the world, not least in Indonesia. The Indonesian government announced the first case of covid-19 in March 2020. All sectors are affected by the covid-19 outbreak, including in the education sector. The Ministry of Education and Culture (Kemdikbud) has implemented a home learning policy (BDR) especially for education units that are in the red, orange, and yellow zones. In contrast to the green zone area, educational units located in the region are allowed to carry out face-to-face learning 
but still have to pay attention to health protocols. This refers to the Joint Decree of the Minister of Education and Culture, Minister of Religious Affairs, Minister of Health and Minister of Home Affairs on Guidance on The Implementation of Learning in the Academic Year 2020/2021 and Academic Year 2020/2021 in the Covid-19 Period. Learning during the covid-19 pandemic forced schools that were originally implemented face-to-face, then required to replace the learning system with a distance system. The Government through the Ministry of Education and Culture issued Circular Letter No. 4 of 2020 on the Implementation of Education Policy in the Emergency Period of COVID Spread. In the Circular Letter it is explained that teaching and learning activities are carried out remotely.

Teaching and learning activities remotely have been contained in the Regulation of the Minister of Education and Culture of the Republic of Indonesia (Permendikbud) Number 119 of 2014 concerning the Implementation of Distance Education at the Level of Primary and Secondary Education. In the Permendikbud explained that distance education (PJJ) is an education whose learners are separate from educators and their learning uses various learning resources through the application of educational / learning technology principles. The approach taken in the conditions of the covid-19 pandemic is to use an online remote approach and an offline remote approach. Schools can use a combination of both approaches based on the ability and availability of school facilities and infrastructure.

From the above exposure, pandemic conditions require PJJ to be done dominantly using an online approach. According to Putra and Irwansyah (2020), online learning is learning that is held without face-to-face or direct physical interaction. The implementation of learning is carried out with the help of internet-based digital applications. Some internetbased applications can be used for learning, such as zoom, google meet, google classroom, quipper, whatsapp, moodle, teacher room, and other applications that allow online learning interaction between teachers and learners through internet technology. By utilizing various internet applications, it is expected that the distance learning process (PJJ) can still run even in pandemic conditions.

Furthermore, looking at the facts of the condition of society during the pandemic, some learners experience some problems. This problem is clearly an obstacle that makes it difficult for learners to get an education in the pandemic period. One of the problems that make it difficult for learners in learning Indonesian online is the availability of learning facilities and weak literacy due to learning from home so as to cause boredom in learning. On the parents' side is also affected by the covid-19 pandemic, for example, having to spend time, expenses, and thoughts to provide facilities and learning assistance for their children. While from the teacher's side also did not escape the impact, for example is unpreparedness in providing learning, learning management, assessment, and supervision (Rigianti, 2020). Teachers become the main motivators in learning, both in pandemic conditions and not. The sudden change of the learning system from the face-to-face system to the remote system due to emigrants must require careful preparation so that learning can run smoothly. Therefore, teachers are required to be able to follow changes in technologybased learning so that the learning process continues to run and students' right to education is still fulfilled even in pandemic conditions.

Based on the description above, the constraints that have been mentioned become important to be studied in order to maximize online Indonesian learning. This literature study and case study is asked a question of research problems, namely how difficult are learners, parents, and teachers in the study of Indonesian in the covid-19 pandemic. The results of this study can be used as materials and reference materials in deciding policies in online learning both learners, parents, teachers, schools and government. 


\section{RESEARCH METHODS}

This research uses case study methods and literature studies or literature research. The steps taken in case studies are by observation and in-person interview at Muhammadiyah 4 Yogyakarta Junior High School, while the literature study is by reading library sources to obtain the necessary data (Arikunto, 2013). The data sources used come from secondary data collected through books, journals, websites, and other sources related to research problems.

This research is qualitative descriptive research. Descriptive methods are carried out to describe the circumstances that occur during research activities at Muhammadiyah 4 Yogyakarta Junior High School, then correlated with data obtained from literature studies. The research data collected was then qualitatively analyzed with Miles and Huberman's models. According to Mile and Huberman (in Sugiyono, 2010), the step in qualitative data analysis is done in an interactive way and continuously until complete. This step must go through several stages including data collection (data collecting), data reduction (data reduction), presentation of data (data display), and conclusion drawing or verification.

\section{RESULTS AND DISCUSSION}

To facilitate in the description, the results of this study are divided into two parts, namely online education policy (distance) during the covid-19 pandemic and learning difficulties Indonesian in the covid-19 pandemic

\section{Online Learning Policy (Remote) during the Covid-19 Pandemic}

The increasing spread of covid-19 makes health for students, teachers, principals, and all school residents a priority. Therefore, the government through the Ministry of Education and Culture of the Republic of Indonesia implements the policy in Circular Letter (SE) Number 4 of 2020 on the Implementation of Education Policy in the Emergency Period of The Spread of Coronavirus Disease (COVID-19).

\section{Providing a Learning Experience}

In Circular Letter (SE) Number 4 of 2020 on the Implementation of Education Policy in the Emergency Period of The Spread of Coronavirus Disease (COVID-19) emphasizes that "Learning from home through online / distance distribution is implemented to provide a meaningful learning experience for students without being burdened with the demands of completing all curriculum achievements for class increase and graduation" (Kemendikbud, 2020).

Online / distance learning has been carried out since march 2020 after instructions from the Ministry of Education and the local Education Office to carry out learning without face-to-face. Based on interviews with the deputy principal of the curriculum section at Muhammadiyah 4 Yogyakarta Junior High School, the learning demands given to students do not have to complete achievements according to the curriculum as usual, but are adjusted to the curriculum of essential materials based on the state of the school environment during the coronavirus outbreak.

In one day, learning is made with a schedule of two to three subjects to ease the burden of students learning remotely and more independently at home than learning previously carried out in school. The task given by the teacher also does not give too heavy a burden. Students are given a period of assignment collection between 1 day to 1 week, even sometimes teachers still give dispensation of late student assignment collection.

Based on the data of interview results to principals, teachers, and students, it can be ascertained that distance learning at Muhammadiyah 4 Yogyakarta Junior High School has 
been in line with government instruction through the Circular Letter (SE) of the Ministry of Education No. 4 of 2020 on the Implementation of Education Policy in the Emergency Period of The Spread of Coronavirus Disease (COVID-19). The burden of assignments given to students does not demand to complete the demands of learning achievement as in the curriculum. This provides a different learning experience to students due to the special thing that is the covid-19 pandemic.

\section{Providing Life Skills Education}

In accordance with the Circular Letter (SE) of the Ministry of Education No. 4 of 2020 on the Implementation of Education Policy in the Emergency Period of The Spread of Coronavirus Disease (COVID-19) emphasizes that distance learning from home refers more to learning life skills education related to covid-19 (Kemendikbud, 2020).

Based on interviews with teachers, instructions given to students related to assignments are related to life skills during the coronavirus outbreak. Some examples of tasks given by teachers to students for example on Indonesian learning are the task of making video readings and posters related to the corona virus. Thus, from the results of the data, researchers found that distance learning at Muhammadiyah 4 Yogyakarta Junior High School has been conducted in accordance with SE (SE) of The Ministry of Education No. 4 of 2020 on the Implementation of Education Policy in the Emergency Period of The Spread of Coronavirus Disease (COVID-19).

\section{Learning in accordance with student conditions}

Learning is carried out online / remotely at SMP Muhammadyah 4 Yogyakarta in accordance with the conditions of students related to the learning facilities used. The learning that students participate in considers affordable access so that it is easy and convenient to use in distance learning. In the process, distance learning requires different facilities and access to each subject. Special subjects Indonesian held at Muhammadiyah 4 Yogyakarta Junior High School using several information technologies, such as $1 \mathrm{~ms}$ moodle, google classroom, google form, zoom, and google meet. From some of these learning applications are used by adjusting the relevant learning conditions and materials for students at that time.

From these learning activities, it can be broadly concluded that SMP Muhammadiyah 4 Yogyakarta has implemented a policy in accordance with the Circular Letter (SE) of the Ministry of Education No. 4 of 2020 on the Implementation of Education Policy in the Emergency Period of The Spread of Coronavirus Disease (COVID-19) as in the quote "Learning activities and tasks learned from Home can vary between students, according to their respective interests and conditions, including considering the gap in access / home study facilities" (Kemndikbud, 2020).

\section{Assessment Process}

In online/distance learning, assessment is not one of the top priorities that students will get. The provision of grades cannot be used as a reference or consideration of boarding classes or student graduation. From interviews conducted with teachers Indonesian, the provision of grades is still in the form of scores or in quantitative form. This shows that the implementation of learning at Muhammadiyah 4 Yogyakarta Junior High School has not implemented a policy in accordance with the Circular Letter (SE) of the Ministry of Education No. 4 of 2020 on the Implementation of Education Policy in the Emergency Period of The Spread of Coronavirus Disease (COVID-19) which reads "Evidence or 
products of Learning from Home activities are given qualitative and useful feedback from teachers, without being required to give quantitative scores / values" (Kemdikbud, 2020).

The conclusion is based on the implementation of learning used using quantitative assessments from media or learning applications LMS Moodle and Google Forms that provide assessment facilities or automatic correction so that the recapitulation of answers automatically has been accompanied by values in accordance with the settings made when the process of making problems.

\section{New Student Admission Process (PPBD) and School Operational Assistance}

In the process of Admission of New Learners (PPDB) is carried out with the provision of following the PPDB mechanism regulated by the local education agency. The mechanism follows health protocols to prevent the spread of covid-19, including the physical gathering of students and parents at school. Some provisions of the PPDB mechanism applied at Muhammadiyah 4 Yogyakarta Junior High School are (a) the accumulation (combined) of report card scores when the school is determined based on the grades of the last five semesters, (b) academic and non-academic achievement outside the school report card, and (c) interviews as part of the selection of admissions of new learners before being declared accepted.

On the other hand, school operational assistance (BOS) funds have also been used for procurement of goods according to school needs including to finance the needs in the prevention of the covid-19 virus pandemic such as the provision of hygiene kits, hand sanitizers, desinfectants, masks, sinks in every school room, temperature gauges, even to compile a task force team handling the spread of the corona virus in schools. With the BOS funding policy, the implementation of online / distance learning can be implemented properly. Thus, the implementation of the New Student Admissions process policy (PPDB) and the School Operational Assistance Fund (BOS) has implemented the directive in accordance with the Circular Letter (SE) of the Ministry of Education No. 4 of 2020 on the Implementation of Education Policy in the Emergency Period of The Spread of Coronavirus Disease (COVID-19).

\section{Learning Constraints Indonesian during the Covid-19 Pandemic}

Online learning in times of pandemic becomes an option that requires to be implemented for educational institutions such as schools. Bifaqih and Qomaruddin (2015) stated that online learning is an in-network classroom program to reach a massive and wide target group. The covid-19 pandemic made educational institutions change the original conventional education model and then change to use the use of internet-based technology features. Various supporting applications are used by teachers to still be able to teach and learners can learn at home during pandemics. Some of the obstacles faced by teachers in learning Indonesian are as follows.

\section{Teacher Constraints}

In an interview with Indonesian teacher at Muhammadiyah 4 Yogyakarta Junior High School and several teachers of The Indonesian Junior High School (MGMP) at Yogyakarta school, admitted that online learning becomes less effective compared to face-to-face learning directly with learners. The difficulties experienced by teachers are some teachers have difficulty in carrying out learning related to learning applications, internet networks when working from home, the use of gadgets, learning management, assessment and supervision (Rigianti, 2020). Another obstacle experienced by teachers is the demand to organize learning Indonesian with internet-connected information technology (Septirini, 
Sumarwati, and Atikah, 2020). This is not surprising because the condition of teachers in Indonesia is not entirely familiar with the use of technology, this can be seen from teachers born before the 1980s. From the constraints of information technology limit them in using online learning media (Aji, 2020).

Aspects of teacher constraints in learning Indonesian can be seen in table 1 below.

Tabel 1. Teacher Constraints

\begin{tabular}{cll}
\hline No & Aspects & Difficulty \\
\hline 1. & Learning applications & Not mastering IT skills \\
\hline 2. & Internet access & Weak internet network \\
\hline 3. & Implementation of learning & Not ready for online learning media \\
\hline 4. & Learning Materials & $\begin{array}{l}\text { Practice, oral and group performance } \\
\text { materials cannot run optimally }\end{array}$ \\
\hline 5. & Student Assessment & $\begin{array}{l}\text { Assessment of processes, practices, } \\
\text { and attitudes }\end{array}$ \\
\hline
\end{tabular}

The difficulty of teachers in organizing online Indonesian learning becomes a problem not only for older teachers, but young teachers also experience the same thing. The unpreparedness of teachers in preparing learning with online systems will have an impact on the decision to teach Indonesian materials by giving more assignments than delivering material using video-based internet applications such as zoom, google meet, whatsapp video, and so on in face-to-face with learners. Technological capabilities are needed by teachers in order to be able to run online learning. Mastery of IT in operating a computer or device will certainly facilitate PJJ learning so that learners still get educational rights as well as face-to-face learning. On the other hand, there are also many positive things that teachers use in online learning to learn self-development such as how to create attractive media for learners, not even a few who become YouTubers from uploading material made for learning learners in their schools.

Another drawback that can be found in learning during the covid-19 pandemic is to focus more on theory, not practice (Shahzad, Hussain, Sadaf, Sarwat, Ghani, \&Saleem: 2020). This is where the material taught to learners also becomes an obstacle for teachers. For example, material from basic competencies that demand learners practice and verbal performance cannot be applied properly in pandemic times. Examples of Indonesian materials that cannot be applied in online learning are materials that demand group performance, such as drama texts. In addition, there are also materials that cannot be applied optimally, including oral retelling materials such as short story texts, poetry text readings, and experimental practices such as procedure texts or trial report texts. Thus the materials demanding the demonstration cannot be applied in pandemic conditions because of circumstances that do not allow face-to-face and to prevent the spread of the covid-19 virus in the school environment.

Another problem that teachers face is assessment in the learning process Indonesian in school. Teachers have difficulty in assessing both process, practice, and attitude. In the time of the covid-19 pandemic, the process clearly could not see firsthand how the process of learners in learning. Teachers only see most of the work of assigned learners. As a result, teachers have difficulty in providing assessment both formatively and summatively. Formative assessment is an assessment carried out during the learning process or submaterial can be completed with the aim to find out the extent of the understanding of learners in understanding the material provided by the teacher (Sudijono in Dasri Rati et al., 2019). Meanwhile, summative assessment is an assessment that is intended to provide basic values for making decisions whether a student can be declared up the class or 
graduated (Daliman in Dasri Rati et al., 2019). From the case in the covid-19 pandemic, teachers have obstacles in providing assessment either formatively or summatively because with the PJJ model can not see directly learners whether doing exam questions honestly, cheating, or getting help from the family(dishonestypractices) so that thequality of learning and learning outcome information obtained from learners is not good.

From the problem of assessment, finally the teacher takes another way in providing assessment to learners, namely by focusing on feedback such as activeness in doing tasks online. This is in line with the opinion of Thomas R. Guskey in Assessment and Grading in the Midst of a Pandemic (2020), stating that in pandemic times, research should focus on feedback (feedback) rather than scoring (grading). Better assessment is focused on formatit assessment, which emphasizes more on how to help learners understand the material properly and correctly so that they are able to achieve the learning goals set even in emergency situations.

\section{Student Constraints}

From the student's side, the difficulties experienced also become serious problems that need to be considered. Learners are the focus of attention not only teachers who teach in schools, but the whole related to education such as government, academia, to parents. Aspects of learners' difficulties that need to be a major concern in learning Indonesian can be seen in table 3 below.

Tabel 2. Student Constraints

\begin{tabular}{cll}
\hline No & Aspects & Difficulty \\
\hline 1. & Learning Facilities & Doesn't have a device \\
\hline 2. & Internet Access & Weak internet network \\
\hline 3. & Liveliness & Inactive when learning \\
\hline 4. & Mental State & Stressed and bored with online learning \\
\hline 5. & Assignment & $\begin{array}{l}\text { Tasks are many and lack understanding of the } \\
\text { learning material well }\end{array}$ \\
\hline 6. & Learning App & Difficulty operating a video conferencing app \\
\hline
\end{tabular}

In the book Good Experience teaching in the Covid-19 Pandemic Mapel Indonesian (Kemdikbud, 2020) there are several obstacles faced by learners making it difficult in the process of learning to teach remotely. As for the difficulties faced by learners, namely:

First, learners do not have a device as a medium for online learning. Even if there is a device, some learners have to wait until their parents come home from work in the afternoon, after which they just do schoolwork. This obviously makes it difficult for learners to follow the learning presented by the teacher. Second, a number of learners do not have adequate internet access so they cannot get tasks that are delivered either through whatsapp groups (WAG) or virtual class groups such as google classroom.

Third, learners are less active and interested in following PJJ even though they are supported by excellent facilities, such as gadgets and smooth internet networks. Lack of awareness of literacy and portfolio task collection often hampers the course of PJJ. Tasks that should have been collected within a week became more frequent to two weeks, even more. This trend is the same as what happened in SMP Muhammadiyah 4 Yogyakarta.

From the results of case studies in schools, learners admit to being bored with online learning systems. Their awareness in literacy becomes reduced especially coupled with assignments, thus causing learners to be hit by saturation in learning from home. Considering that PJJ learning has lasted more than one semester since March 2020, according to some learners become boring and lazy because they use the PJJ system for too 
long. Problems related to technical problems often arise in technology-based learning. As rinekso and Muslim (2020) found that chats in whatsapp groups(WAG) often accumulate and it makes learners always lazy to scroll through chats. In this case, learners must find good internet access and use a laptop / PC (for those who have) to make the process of scrolling up easier in following learning.

In addition, learners also admitted to stress with the many tasks given by teachers. In line with the opinion of K. James Hartshorn and Benjamin L. McMurry $(2020,149)$ said that the task of sekolah is the most difficult challenge during a pandemic. Many have problems using and adapting to technology. One of the students at Muhammadiyah 4 Yogyakarta Junior High School said "I had to get out of the house in order to do midterm assignments and exams (PTS) and End-of-Semester Assessment (PAS) due to a weak internet network". Another case with networking, there are also learners who claim to have difficulty using the video conferencing application "Zoom (video conferencing platform) is not easy to use because some sounds during the lesson become bullies, so they cannot follow the lesson properly". There are also learners who provide comments to invite entry (learning) in school because of difficulty doing tasks. Such learners realize that their schoolwork is difficult due to a lack of opportunities to speak and listen outside the classroom.

\section{Parent Constraints}

Parents are also affected by the covid-19 pandemic. Parents who usually give their children their overall education in school, now in the pandemic period becomes a feel how difficult it is to educate school children even through online learning at home. Parents seem to be teachers who have to teach material when children have difficulty in doing tasks from the teacher. The difficulties that parents feel for children during online learning can be seen in table 3 below.

Tabel 3. Parent Constraints

\begin{tabular}{lll}
\hline No & Aspects & Difficulty \\
\hline 1. & $\begin{array}{l}\text { Social - } \\
\text { economic }\end{array}$ & $\begin{array}{l}\text { Low economic ability for daily needs, such as basic } \\
\text { needs and children's internet data packages }\end{array}$ \\
\hline 2. & Education & $\begin{array}{l}\text { Supervision and mentoring of online learning at } \\
\text { home }\end{array}$ \\
\hline
\end{tabular}

The impact in the socioeconomic field, for example, different gaps cause the carrying capacity of learners to follow distance learning is also different from each other. For example, there are still learners who do not have a smart phone because of the inability of parents to buy. For those who can afford to buy a device also has the problem of limitations of internet data packages that can be purchased by parents. Indeed, the government provides internet data package subsidy assistance, but the distribution is still uneven.

The impact is not only in the socioeconomic field, but the field of education also feels the difficulty. The difficulty comes from his son who is going to school. Parents automatically become substitute teachers at home for their children who have difficulty learning from materials delivered by teachers at school. On the other hand, for parents who work outside the home, whether working in the government, private, or self-employed sectors, they have difficulty because they cannot accompany their children in learning. When school runs online, the role of parents becomes increased for their children because they have to supervise education, guarantee food needs, and manage the child's emotional level if they have difficulty in learning. As a result, that's when there is often conflict with the family because on the other hand parents have to work as usual. 
Another case for parents who work as teachers and have children who are studying online, they even take their children to the school where their parents work. The reason is none other than to ask for the help of other teachers (co-workers) to help their child learn. In observations at where the researcher's school worked, researchers were even asked by colleagues (teachers) at the school to help learn their children who attended other schools to work on problems Indonesian that felt difficult. With this phenomenon it can be said that for an educator also has difficulty in educating his own child in learning in school.

\section{CONCLUSION}

Online learning policies are implemented to suppress the increasing spread of Covid-19. Health is the main focus for students, teachers, principals, and all school residents, and becomes a government policy that must be adhered to by all education units in order to achieve healthy and safe education actors. Therefore, the government through the Ministry of Education and Culture of the Republic of Indonesia implements the policy in Circular Letter (SE) Number 4 of 2020 on the Implementation of Education Policy in the Emergency Period of The Spread of Coronavirus Disease (COVID-19) which contains about policies: (a) provides student learning experience, (b) provides life skills education, (c) learning in accordance with student conditions, (d) the process of giving assessment, and (d) the process of Accepting New Learners (PPDB) and School Operational Assistance (BOS).

Online learning in the covid-19 pandemic also has various difficulties experienced by teachers, learners, and parents. Difficulties experienced by teachers in aligning Indonesian materials include aspects of mastery of learning applications such as zoom, google meet, lms moodle, google classroom, etc. Other aspects are weak internet access, aspects of unprepared learning implementation, aspects of learning materials that demand practical, oral, and group performance cannot run optimally, and aspects of difficulty in providing assessment to learners. While from the student side also has obstacles that become difficulty in learning Indonesian, namely aspects of home learning facilities that do not meet for distance learning, weak internet network access, the number of tasks given by teachers so as to cause psychological conditions of stress and boredom. As a result, learners are not active in following the learning. In addition, there are also aspects of difficulty in operating applications such as zoom that are considered complicated. On the parents' side, the difficulties experienced are more to socio-economic aspects, such as low in meeting daily needs to the needs of children's internet data packages. In the aspect of education, parents also have difficulty in the supervision and assistance of children's online learning at home.

\section{ACKNOWLEDGMENT}

Thanks were conveyed to all teachers, students of Muhammadiyah 4 Yogyakarta Junior High School, and MGMP teachers Indonesian Yogyakarta City who had helped the implementation of research until it was realized into this article. Hopefully, this paper can provide benefits for improving the quality of Indonesian learning in distance learning, both in the covid-19 pandemic and when it is in normal times such as face-to-face learning in school.

\section{REFERENCES}

Aji, Rizqon H. S., (2020). Dampak Covid-19 pada Pendidikan di Indonesia: Sekolah, Keterampilan, dan Proses Pembelajaran. SALAM: Jurnal Sosial \& Budaya Syar-i, 7 (5), 395-402. DOI: http://dx.doi.org/10.15408/sjsbs.v7i5.15314 
Arikunto, Suharsimi. (2013). Prosedur Penelitian: Suatu Pendekatan Praktik. Jakarta: Rineka Cipta.

Bifaqih, Yusuf, \& Qomaruddin, M. N. (2015) Esensi Pengembangan Pembelajaran Daring. Yogyakarta: Deepublish.

Guskey, Thomas R. (2020). Assessments and Grading in the Midst of a Pandemic. Retrieved from http://tguskey.com/assessments-and-grading-in-the-midst-of-apandemic/

Hartshorn, K. J. \& McMurry, B. L. (2020). The Effects of the COVID-19 Pandemic on ESL Learners and TESOL Practitioners in the United States. Internasional Journal of TESOL Studies, 2 (2), 140-156. DOI: https://doi.org/10.46451/ijts.2020.09.11

Keputusan Bersama Menteri Pendidikan dan Kebudayaan, Menteri Agama, Menteri Kesehatan dan Menteri Dalam Negeri No. 01/KB/2021, No. 516 Tahun 2020, No. HK.03.01/Menkes/363/2020, dan No. 440-882 tentang Panduan Penyelenggaraan Pembelajaran pada Tahun Ajaran 2020/2021 dan Tahun Akademik 2020/2021 di Masa Covid-19.

Nusantari, S. S., Sumarwati, \& Anindyarini A. (2020). Pembelajaran Bahasa Indonesia Secara Online Pada Masa Pandemi COBID-19 Di SMA Islam Terpadu Nur Hidayah Sukoharjo. Basastra: Jurnal Bahasa, Sastra, dan Pengajarannya, 8 (2), 206-214. DOI: https://doi.org/10.20961/basastra.v8i2.45312

Peraturan Menteri Pendidikan dan Kebudayaan Republik Indonesia No. 119 Tahun 2014 tentang Penyelenggaraan Pendidikan Jarak jauh Jenjang Pendidikan Dasar dan Menengah.

Putra, R., \& Irwansyah, I. (2020). Media Komunikasi Digital, Efektif namun Tidak Efisien, Studi Media Richness Theory dalam Pembelajran Jarak Jauh Berbasis Teknologi di Masa Pandemi. Jurnal Ilmu Sosial dan Politik, 1(2), 1-13.

Rati, Dasri, Suryanef, \& Montessori, Maria. (2019). Pelaksanaan Penilaian Formatif dalam Pembelajaran PPKn di SMP N 2 Lengayang. JCE, 2 (1), 106-115. DOI: https://doi.org/10.24036/jce.v2i1.106

Rinekso, A. B., \& Muslim, A. B. (2020). Synchronous Online Discussion: Teaching English in Higher Education Admist the Covid-19 Pandemic. JEES (Journal of English Educators Society), 2 (2) 155-162. DOI: https://doi.org/10.21070/jees.v5i2.646

Surat Edaran No. 4 tahun 2020 tentang Pelaksanaan Kebijakan Pendidikan dalam Masa darurat Penyebaran Coronavirus Disease (COVID-19). 